\title{
PENGARUH MODEL PEMBELAJARAN TERHADAP KEMAMPUAN BERPIKIR KRITIS DITINJAU DARI POTENSI AKADEMIK PESERTA DIDIK KELAS XI SMA NEGERI 1 KENDARI
}

\author{
Hartina Pratiwi ${ }^{\text {I) }}$ Hafiludin Samparadja ${ }^{2)}$ La Arapu ${ }^{3)}$ \\ ${ }^{1)}$ Alumni Jurusan Pendidikan Matematika, ${ }^{2,3)}$ Dosen Jurusan Pendidikan Matematika \\ FKIP Universitas Halu Oleo Email: tina.la.mela96@gmail.com; \\ hafiludin79@yahoo.com; laarapu@gmail.com
}

\begin{abstract}
Abstrak
Penelitian ini dilatar belakangi oleh rendahnya kemampuan berpikir kritis matematis peserta didik. Populasi dalam penelitian ini adalah seluruh peserta didik kelas XI MIPA SMA Negeri 1 Kendari yang terdiri dari 9 kelas paralel berjumlah 324. Pengambilan sampel menggunakan teknik clusterd random sampling sehingga diperoleh XI MIPA 5 sebagai kelas eksperimen dan kelas XI MIPA 6 sebagai kelas kontrol. Teknik pengumpulan data menggunakan tes potensi akademik dan tes kemampuan berpikir kritis. Berdasarkan hasil analisis data dan pembahasan diperoleh kesimpulan: (1)kemampuan berpikir kritis peserta didik setelah diberi perlakuan model pembelajaran dengan potensi akademik memiliki rerata, simpangan baku, dan skewness yang berbeda antar tiap kelompok; ( 2 terdapat perbedaan rerata yang signifikan dari faktor model pembelajaran terhadap kemampuan berpikir kritis; (3)terdapat perbedaan kemampuan berpikir kritis antara peserta didik yang mempunyai potensi akademik tinggi, sedang, dan rendah; (4)tidak terdapat interaksi antara model pembelajaran matematika dengan potensi akademik peserta didik terhadap kemampuan berpikir kritis.
\end{abstract}

Kata Kunci: Model pembelajaran, kemampuan berpikir kritis, potensi akademik peserta didik.

\section{THE EFFECT OF LEARNING MODELS TOWARDS CRITICAL THINKING ABILITY IN TERMS OF STUDENT ACADEMIC POTENTIAL OF 11TH GRADE ON SENIOR HIGH SCHOOL 1 KENDARI}

\begin{abstract}
This research was motivated by critical low-thinking ability students. The population in this research were all of students of XI MIPA on Senior High School 1 Kendari which distributed randomly in 9 parallel group. It is 324 students. The sample was determined by cluster random sampling technique it is XI MIPA 5 as an experimental group and class XI MIPA 6 as a control group. Data obtained using instruments by student critical thinking test and academic potential test. Based on the results of data analysis and discussion, conclusions were obtained: (1)the critical thinking ability of students after being treated with learning models and academic potential have a mean, standard deviation, and different skewness coefficient between groups; (2)there were significant differences in the mean of the learning model factors on the ability to think critically; (3)there were differences in critical thinking ability of students who have high, medium, and low academic potential; (4)there is no interactions between of mathematics learning models with student academic potential towards critical thinking ability.
\end{abstract}

Keywords: learning models, critical thinking ability, academic potential of students. 


\section{Pendahuluan}

Hendriana dan Soemarmo (2014: 13) menjelaskan bahwa matematika sebagai matematika sekolah dapat dilihat dari empat aspek yaitu penyajian, pola pikir, semesta pembicaraan, dan tingkat keabstrakan, penyajian tidak harus diawali dengan teorema maupun definisi, pola pikir yang digunakan dapat secara deduktif maupun induktif. Sesuai dengan tingkat perkembangan intelektual peserta didik, maka matematika disajikan dalam kompleksan semestanya. Semakin meningkat tahap perkembangan intelektual peserta didik maka semesta matematikanya semakin meningkat. Demikian pula dengan tingkat keabstrakan matematika harus menyesuaikan dengan tingkat perkembangan intelektual peserta didik.

Menurut Spearman (Afiah, 2012: 4) inteligensi terdiri dari kemampuan umum yang bekerja sama dengan kemampuan-kemampuan khusus. Oleh karena itu, untuk membedakannya seringkali digunakan istilah inteligensi umum (general intelligence) dan potensi khusus (special aptitude). Potensi khusus sering dikaitkan dengan lapangan-lapangan khusus dalam kehidupan seperti potensi mekanik, potensi menyanyi, dan sebagainya.

Tes potensi merupakan salah satu bentuk pengukuran terhadap kemampuan abilitas kognitif potensial umum yang dirancang khusus guna memprediksi keberhasilan belajar di jenjang yang lebih tinggi, karena itulah tes seperti ini biasanya dinamai Tes Potensi Akademik (Azwar, 2008: 1). Tes Potensi Akademik atau yang biasa disingkat TPA merupakan tes yang mengukur kemampuan berpikir peserta didik meliputi kemampuan pemahaman dan penalarannya saat ini. Tingkat kemampuan berpikir peserta didik ditentukan oleh kapasitas berpikir dan pengalamannya di dalam maupun luar sekolah, dan kemampuan berpikir ini berkembang sejak ia lahir hingga saat ini. TPA mengukur kemampuan berpikir peserta didik dari tiga aspek, yaitu verbal, numerikal, dan figural. Kemampuan verbal merupakan kemampuan pemahaman dan bernalar dengan menggunakan bahasa, kemampuan numerikal merupakan kemampuan pemahaman dan bernalar dengan menggunakan angka, dan kemampuan figural merupakan kemampuan pemahaman dan bernalar dengan menggunakan gambar (http:// psikologi.unair .ac.id).
Hasil dari nilai TPA dapat digunakan sebagai profil kemampuan berpikir peserta didik (berpikir dengan bahasa, angka, atau gambar) yang dapat dipergunakan oleh guru untuk mengembangkan proses pembelajaran di kelas untuk membantu peserta didik secara individual. Sehingga proses pembelajaran peserta didik akan lebih efektif dan optimal karena peserta didik dapat memaksimalkan potensi kemampuan berpikirnya dalam belajar.

Peserta didik yang memiliki kemampuan berpikir yang tinggi akan memiliki proses berpikir dan strategi pemecahan masalah yang efektif dan efisien yang membuatnya lebih mudah mempelajari mata pelajaran di sekolah dan menyelesaikan persoalan, sehingga akan memiliki prestasi belajar yang baik.

Salah satu kemampuan berpikir yang harus dikembangkan oleh peserta didik adalah kemampuan berpikir kritis. Menurut Johnson (2012: 185) tujuan dari berpikir kritis adalah untuk mencapai pemahaman yang mendalam. Pemahaman membuat kita mengerti maksud dibalik ide yang mengarahkan hidup kita setiap hari. Pemahaman mengungkapkan makna dibalik suatu kejadian.

Secara lebih lanjut The Partnership for 21st Century Skills (2011) merumuskan konten isi akademik berupa 3Rs (Reading, Writing, Aritmethic) dan 4Cs yakni critical thinking (berpikir kritis dan pemecahan masalah), creativity and innovation (kreativitas-inovasi), communication skill (kemampuan berkomunikasi), collaboration (kolaborasi) yang mendasari kemampuan berpikir tingkat tinggi (Nugroho, 2018: 5). Dari penjelasan tersebut tampak bahwa seorang peserta didik tidak cukup dibekali dengan ilmu pengetahuan dari pembelajaran sehari-hari (key subject-3Rs), tetapi juga harus dibekali dengan perangkat yang memampukan peserta didik menghadapi situasi abad 21. Pembelajaran diarahkan pada 4Cs tersebut. Ini berarti lingkungan belajar menjadi hal yang sangat penting dalam mengembangkan kemampuan berpikir peserta didik.

Hasil survei Programme for International Student Assesment (PISA) dan Trends in International Match and Survey (TIMSS) menunjukkan bahwa peringkat peserta didik Indonesia belum mampu menempati posisi atas. Kedua survei tersebut menunjukkan bahwa mayoritas peserta didik di Indonesia berada pada tataran tingkat berpikir rendah. Hal ini 
mengindikasikan bahwa literasi sains peserta didik masih rendah. Proses, isi, dan aplikasi sains dan matematika masih belum sesuai harapan. Kemampuan berpikir masih cenderung mengingat (recall), menyatakan kembali (restate), atau merujuk tanpa melakukan pengolahan (recite) (Nugroho, 2018: 11).

Berdasarkan hasil observasi awal yang dilakukan di SMA Negeri 1 Kendari pada tanggal 2 Agustus 2018 melalui wawancara salah satu guru mata pelajaran matematika diketahui bahwa setiap peserta didik memiliki kemampuan yang berbeda-beda dalam menyelesaikan soal matematika. Ada peserta didik yang perlu terus diberikan motivasi dan bimbingan agar dapat memahami materi. Kelas XI SMA Negeri 1 Kendari terdiri atas sembilan kelas jurusan MIPA dan lima kelas jurusan IPS. Dari sembilan kelas jurusan MIPA, Kelas XI MIPA 3 hingga kelas MIPA 9 memiliki peserta didik yang kemampuannya relatif sama. Walaupun tidak ada program kelas unggulan, tetapi dua kelas MIPA lainnya hampir $60 \%$ peserta didiknya merupakan peserta bimbingan olimpiade di sekolah tersebut.

Berdasarkan wawancara dengan guru matematika kelas XI MIPA 5 dan XI MIPA 6 diketahui bahwa sebagian peserta didik memiliki kemampuan berpikir kritis yang kurang. Hal ini tampak dari nilai rata-rata kelas dalam ulangan harian yang memuat indikator berpikir kritis yakni 63,96 dan 63,72 . Sebagian peseta didik juga harus dibantu terlebih dahulu oleh guru atau teman agar dapat memahami materi dan menyelesaikan soal. Mereka juga kurang memiliki kemampuan mengidentifikasi permasalahan yang terdapat dalam soal. Beberapa peserta didik juga belum mampu memberikan alasan suatu pertanyaan yang memerlukan umpan balik.

Pembelajaran matematika yang diberikan di sekolah diharapkan dapat membuat peserta didik menjadi mandiri dalam menyelesaikan masalah. Berdasarkan hasil wawancara, diketahui bahwa pembelajaran matematika yang dilakukan di kelas XI ialah model pembelajaran discovery learning dan problem based learning. Dari hasil wawancara guru matematika kelas XI MIPA 1 dan XI MIPA 2 menggunakan model pembelajaran problem based learning atau pembelajaran berbasis masalah. Sedangkan untuk XI MIPA 3 dan XI MIPA 4, pembelajaran yang dilaksanakan adalah keduanya. Sedangkan untuk XI MIPA lainnya adalah pembelajaran discovery learning. Walaupun demikian, masih banyak peserta didik yang belum mampu menyelesaikan soal matematika secara mandiri.

Trianto (2007: 44) menjelaskan bahwa pembelajaran kooperatif dapat membantu peserta didik menumbuhkan kemampuan berpikir kritis. Pembelajaran kooperatif menuntut peserta didik untuk berdiskusi dalam kelompok secara aktif dan positif serta tetap menghargai ide-ide yang dikemukakan oleh teman satu kelompoknya. Sehingga dalam pembelajaran ini akan tercipta interaksi yang lebih luas baik antara peserta didik dengan peserta didik maupun peserta didik dengan guru yang dapat menumbuhkan kemampuan berpikir kritis peserta didik.

Salah satu tipe model pembelajaran kooperatif adalah Team Assisted Individualization. Casal mengungkapkan bahwa strategi pembelajaran ini dikembangkan oleh Slavin, Leavy dan Madden. Strategi ini bersifat khusus dikembangkan untuk pembelajaran matematika. Team Assisted Individualization menggabungkan antara metode pembelajaran kooperatif dan pengajaran klasikal berbasis individual (Warsono dan Hariyanto, 2012: 198-199). Bantuan individu dalam kelompok ini mendorong peserta didik untuk berpikir baik secara individual maupun dalam suatu tim kompetitif terhadap tim lain.

$\begin{array}{cccr}\text { Unsur } & \text { dalam } & \text { Team } & \text { Assisted } \\ \text { Individualization } & \text { yang } & \text { diduga } & \text { dapat }\end{array}$ meningkatkan kemampuan berpikir kritis adalah pada saat belajar individu peserta didik dilatih untuk mengidentifikasi suatu permasalahan serta membuat langkah penyelesaian masalah dan pada saat diskusi kelompok, peserta didik saling bertukar pendapat untuk menyelesaikan suatu masalah. Peserta didik diharuskan bertanggung jawab atas semua pengecekan jawaban yang dikerjakan oleh teman satu kelompoknya. Pada saat pengecekan itu peserta didik dilatih berpikir kritis untuk menganalisis jawaban temannya dan menarik kesimpulan mana yang benar dan mana yang salah.

Berdasarkan latar belakang di atas, maka penulis melakukan penelitian dengan judul "Pengaruh Model Pembelajaran Kooperatif tipe Team Assisted Individualization terhadap 


\section{Jurnal Penelitian Pendididikan Matematika Volume 7 No.2 Mei 2019}

Kemampuan Berpikir Kritis Ditinjau dari Potensi Akademik Peserta Didik Kelas XI SMA Negeri 1 Kendari”.

\section{Metode}

Penelitian ini adalah penelitian eksperimen semu dan dilaksanakan pada semester ganjil tahun ajaran 2018/2019 di SMA Negeri 1 Kendari. Populasi dalam penelitian ini adalah seluruh peserta didik kelas XI MIPA yang secara akademik tersebar pada 9 kelas yaitu Kelas XI MIPA 1 sampai dengan XI MIPA 9 yang berjumlah 324. Pengambilan sampel dari kesembilan kelas tersebut dilakukan dengan teknik cluster random sampling yaitu pengambilan sampel secara acak dari seluruh kelas XI MIPA yang memiliki karakteristik yang sama. Satu kelas digunakan sebagai kelompok eksperimen dengan penerapan pembelajaran kooperatif tipe Team Assisted Individualization dan satu kelas lainnya lagi sebagai kelompok kontrol dengan pembelajaran Discovery Learning. Setelah dilakukan pemilihan sampel penelitian diperoleh kelas XI MIPA 5 dengan jumlah peserta didik 36 sebagai kelas eksperimen dan kelas XI MIPA 6 berjumlah 36 sebagai kelas kontrol.

Variabel dalam penelitian ini terdiri dari dua variabel bebas (independen) dan satu variabel terikat (dependen). Variabel bebas tersebut adalah model pembelajaran kooperatif tipe Team Assisted Individualization pada kelas eksperimen dan model pembelajaran Discovery Learning pada kelas kontrol. Kedua kelompok tersebut diasumsikan sama dalam segi yang relevan dan hanya berbeda dalam perlakuan yang berbeda. Untuk variabel bebas lainnya adalah potensi akademik peserta didik dan variabel terikatnya adalah kemampuan berpikir kritis matematis. Desain penelitian ini adalah desain faktorial dengan rancangan faktorial $2 \times 3$ sebagai berikut.

\section{Tabel 1}

Desain Penelitian dengan Desain Faktorial

\begin{tabular}{|c|c|c|c|}
\hline \multirow{2}{*}{ Kelompok $(a)$} & \multicolumn{3}{|c|}{ Potensi Akademik $(b)$} \\
\cline { 2 - 4 } & Tinggi $\left(b_{1}\right)$ & Sedang $\left(b_{2}\right)$ & Rendah $\left(b_{3}\right)$ \\
\hline Eksperimental $\left(a_{1}\right)$ & $a_{1} b_{1}$ & $a_{1} b_{2}$ & $a_{1} b_{3}$ \\
\hline Kontrol $\left(a_{2}\right)$ & $a_{2} b_{1}$ & $a_{2} b_{2}$ & $a_{2} b_{3}$ \\
\hline
\end{tabular}

berkategori tinggi berarti memiliki tingkat

Keterangan:

$a_{1}=$ model pembelajaran kooperatif tipe Team

Assisted Individualization

$a_{2}=$ model pembelajaran Discovery Learning

$b_{1}=$ potensi akademik peserta didik tinggi

$b_{2}=$ potensi akademik peserta didik sedang

$b_{3}=$ potensi akademik peserta didik rendah

$a b=$ kemampuan berpikir kritisInstrumen penelitian yang digunakan dalam penelitian ini adalah tes potensi akademik dan tes kemampuan berpikir kritis matematis. Secara operasional, Potensi akademik yang dimaksud dalam penelitian ini adalah sejumlah skor dari tes potensi akademik yang terbagi menjadi empat jenis tes yaitu (1) tes kemampuan verbal; (2) tes kemampuan numerik; (3) tes kemampuan penalaran; dan (4) tes kemampuan visual spasial (Sarwadi, 2015:4-5). Skor yang telah diperoleh darai TPA kemudian dikelompokkan kedalam kategori tinggi, sedang, dan rendah yang disesuaikan dengan pedoman pangkategorian penskoran. Untuk peserta didik yang memperoleh skor tes potensi akademik yang potensi akademik tinggi, untuk peserta didik

yang memperoleh skor tes potensi akademik yang berkategori sedang berarti memiliki tingkat potensi akademik sedang, dan untuk peserta didik yang memperoleh skor tes potensi akademik yang berkategori rendah berarti memiliki tingkat potensi rendah. Adapun distribusi data potensi akademik peserta didik kelas eksperimen dan kelas kontol, dengan kriteria sebagai berikut.

1. Potensi akademik tinggi $=X_{i}>\bar{X}+\frac{1}{2} S D$

2. Potensi akademik sedang $=\bar{X}-\frac{1}{2} S D \leq$ $X_{i} \leq \bar{X}+\frac{1}{2} S D$

3. Potensi akademik rendah $=X_{i}<\bar{X}-\frac{1}{2} S D$

Kemampuan berpikir kritis secara operasional adalah tingkat penguasaan dan kemampuan yang dicapai oleh peserta didik yang dituangkan dalam bentuk nilai setelah proses pembelajaran matematika. Adapun 
indikator kemampuan berpikir kritis yang digunakan adalah (1) mengidentifikasi permasalahan, (2) membuat langkah penyelesaian, (3) menganalisis dan mengklarifikasi suatu pernyataan, dan (4) membuat kesimpulan secara generalisasi.

Instrumen penelitian yang digunakan terlebih dahulu dilakukan uji validitas dan reliabilitas. Untuk uji validitas, rumus yang digunakan adalah rumus product moment Pearson yaitu sebagai berikut:

$r_{x y}=\frac{N \sum x y-\left(\sum x\right)\left(\sum y\right)}{\sqrt{\left\{\left(N \sum X^{2}\right)-\left(\sum X\right)^{2}\right\}\left\{\left(N \sum Y^{2}\right)-\left(\left(\sum Y\right)^{2}\right)\right\}}}$

Keterangan :

$r_{x y} \quad$ : Koefisien korelasi antara variabel $\mathrm{X}$ dan variabel $\mathrm{Y}$

$\sum Y \quad$ : Skor item soal

$\sum X \quad:$ Skor total

$N \quad$ : Banyak subjek

(Poerwanti, 2008: 34).

Uji validitas instrumen dilakukan untuk membandingkan hasil perhitungan $r_{x y}$ dengan $\mathrm{r}_{\text {tabel }}$ pada taraf signifikansi $5 \%$, dengan terlebih dahulu menetapkan degrees of freedom atau derajat kebebasan yaitu $\mathrm{dk}=\mathrm{n}$. Dengan kriteria validasi, jika $r_{\text {hitung }} \geq r_{\text {tabel }}$ maka butir valid dan jika $r_{\text {hitung }}<r_{\text {tabel }}$ maka butir tidak valid. Hasil uji tes potensi akademik dari 60 butir soal diperoleh 45 item valid. Hasil uji tes kemampuan berpikir kritis peserta didik pada materi transformasi dari 10 butir soal diperoleh 9 item valid

Pengukuran tingkat reliabilitas instrumen tes potensi akademik digunakan perhitungan K-R 20 sebagai berikut.

Keterangan:

$$
r_{11}=\left(\frac{n}{n-1}\right)\left(\frac{S^{2}-\Sigma p q}{S^{2}}\right)
$$

$r_{11}=$ reliabilitas tes secara keseluruhan

$\mathrm{p}=$ proporsi subjek yang menjawab item dengan benar

$\mathrm{q}=$ proporsi subjek yang menjawab item dengan salah $(\mathrm{q}=1-\mathrm{p})$

$\sum \mathrm{pq} \quad=$ jumlah hasil perkalian antara $\mathrm{p}$ dan $\mathrm{q}$

$\mathrm{n} \quad=$ banyaknya item

$\mathrm{S} \quad=$ standar deviasi dari tes (standar

deviasi adalah akar variansi)

(Arikunto, 2017: 115)
Untuk menghitung tingkat keterandalan dari butir tersebut dipakai rumus Alpha Cronbach, yaitu sebagai berikut.

$$
r_{i t}=\left(\frac{n}{n-1}\right)\left(1-\frac{\sum s_{i}^{2}}{s_{t}^{2}}\right)
$$

Keterangan:

$\mathrm{n}$ = Banyaknya item

$s_{i}{ }^{2}=$ Jumlah varians skor tiap

$s_{t}{ }^{2}=$ Varians skor total

(Jihad dan haris, 2012: 180)

Koefisien reliabilitas sebesar 0,5 menunjukkan bahwa tes itu memilki reliabilitas yang kurang baik. Kebanyakan tes-tes yang standar untuk pengukuran di bidang pendidikan umumnya memilki koefisien reliabilitas minimal 0,8 untuk populasi yang sesuai. Sedangkan menurut Jihad dan Haris (2012 : 181) koefisien reliabilitas antara 0,7 sampai 0,9 dikategorikan tinggi dan 0,9 sampai 1,0 dikatakan reliabilitas sangat tinggi untuk suatu penelitian. Sehingga dalam penelitian ini tes dikatakan reliabel jika $0,70<r_{11} \leq 1,00$.

Hasil analisis reliabilitas instrumen tes potensi akademik diketahui soal memilki tingkat reliabilitas yakni 0,906 sehingga reliabel untuk digunakan. Sedangkan untuk instrumen tes kemampuan berpikir kritis diketahui soal memiliki tingkat reliabilitas yakni 0,759268 sehingga layak digunakan untuk mengukur kemampuan berpikir kritis peserta didik kelas XI MIPA SMA Negeri 1 Kendari.

Teknik pengumpulan data yang dilakukan pada penelitian ini adalah metode tes dan observasi. Tes ini berupa tes kemampuan berpikir kritis matematis dan tes potensi akademik. Tes kemampuan berpikir kritis digunakan untuk mengukur kemampuan berpikir kritis matematis peserta didik pada materi transformasi. Tes akan diberikan kepada kedua kelas setelah dilakukan perlakuan. Pemilihan bentuk soalnya berupa soal essay yang disesuaikan dengan indikator kemampuan berpikir kritis matematis peserta didik dalam pembelajaran transformasi. Tes potensi akademik digunakan untuk mengukur tingkat potensi akademik peserta didik. Tes potensi akademik peserta didik akan diberikan kepada peserta didik setelah dilakukan pembelajaran. Observasi dalam penelitian ini bertujuan untuk 


\section{Jurnal Penelitian Pendididikan Matematika Volume 7 No.2 Mei 2019}

melihat keterlaksanaan pembelajaran melalui model pembelajaran kooperatif tipe TAI.

Analisis data dalam penelitian ini dilakukan dengan menggunakan dua jenis analisis, yaitu analisis deskriptif dan analisis inferensial. Analisis deskriptif dimaksudkan untuk mendeskripsikan atau menggambarkan variabel-variabel penelitian. Analisis deskriptif perhitungan kemampuan berpikir matematis peserta didik dan potensi akademik dilakukan agar diketahui gambaran mengenai tingkat kemampuan berpikir kritis peserta didik, potensi akademiknya. Hasil tes kemampuan berpikir kritis matematis dan tes potensi akademik dalam bentuk rata-rata $(\bar{X})$, median (Me), Modus(Mo), data minmum (Min), data maksimum (Maks), dan standar deviasi atau simpangan baku (s). Setelah diperoleh reratanya, maka diperoleh ukuran kecondongan data dalam kurva. Kecondongan ini dinamakan kemiringan atau Skewness.

Tahap selanjutnya dalam analisis data adalah analisis inferensial. Dalam analisis inferensial, terdapat beberapa tahap analisis yang menjadi prasyarat untuk melakukan analisis uji hipotesis yaitu analisis uji normalitas data dan analisis uji homogenitas data. Setelah melalui syarat uji normalitas dan uji homogenitas maka dilanjutkan dengan uji hipotesis menggunakan analisis varians dua jalan 2x3. Pada analisis variansi dua jalan dengan sel tak sama, digunakan langkahlangkah sebagai berikut

1. Menghitung Jumlah Kuadrat (JK) untuk beberapa sumber variansi, yaitu Total (T), Antar (A), Antar (B), Interaksi (AB), dan Dalam (D), dengan

2. Menentukan derajat kebebasan (db) masing-masing sumber varians

3. Menentukan Rata-rata Jumlah Kuadrat (RJK)

4. Menentukan $\mathrm{F}_{\mathrm{o}}$

Kriteria pengujiannya adalah, jika $\mathrm{F}_{\mathrm{o}}>$ $F_{\text {tabel }}$ pada taraf signifikan yang dipilih dengan $\mathrm{db}$ pembilang adalah db yang sesuai, maka $\mathrm{H}_{0}$ ditolak. Sebaliknya untuk $\mathrm{F}_{\mathrm{o}} \leq \mathrm{F}_{\text {tabel }}$ maka $\mathrm{H}_{0}$ diterima (Kadir, 2018:349-351). Rangkuman Analisis Variansi dapat dilihat pada tabel berikut.

Tabel 2

Rangkuman ANOVA Dua Jalan

\begin{tabular}{|c|c|c|c|c|c|}
\hline $\begin{array}{c}\text { Sumber } \\
\text { Varians }\end{array}$ & JK & db & \multirow{2}{*}{ RJK } & \multirow{2}{*}{ F $_{\mathbf{o}}$} & $\mathbf{F}_{\text {tabel }}$ \\
\cline { 4 - 6 } & & & & & $\boldsymbol{\alpha}=\mathbf{0 , 0 5}$ \\
\hline Antar $(\mathrm{A})$ & $\mathrm{JK}(\mathrm{A})$ & $\mathrm{n}_{\mathrm{a}}-1$ & $\mathrm{RJK}(\mathrm{A})$ & $\mathrm{F}_{\mathrm{oA}}$ & $\mathrm{F}^{*}$ \\
\hline Antar $(\mathrm{B})$ & $\mathrm{JK}(\mathrm{B})$ & $\mathrm{n}_{\mathrm{b}}-1$ & $\mathrm{RJK}(\mathrm{B})$ & $\mathrm{F}_{\mathrm{oB}}$ & $\mathrm{F}^{*}$ \\
\hline Int. AB & $\mathrm{JK}(\mathrm{AB})$ & $\left(\mathrm{n}_{\mathrm{a}}-1\right)\left(\mathrm{n}_{\mathrm{b}}-1\right)$ & $\mathrm{RJK}(\mathrm{AB})$ & $\mathrm{F}_{\mathrm{oAB}}$ & $\mathrm{F}^{*}$ \\
\hline Dalam $($ Error $)$ & $\mathrm{JK}(\mathrm{D})$ & $\mathrm{n}_{\mathrm{t}}-\left(\mathrm{n}_{\mathrm{a}}\right)\left(\mathrm{n}_{\mathrm{b}}\right)$ & $\mathrm{RJK}(\mathrm{D})$ & - & - \\
\hline Total & $\mathrm{JK}(\mathrm{T})$ & $\mathrm{n}_{\mathrm{t}}-1$ & - & - & - \\
\hline
\end{tabular}

Apabila $\mathrm{H}_{0}$ ditolak maka perlu dilakukan uji pasca anava. Metode yang digunakan untuk uji lanjut pasca anava dua jalan adalah metode Scheffe. Langkah-langkah dalam menggunakan Metode Schefe adalah sebagai berikut.

1. Mengidentifikasi semua pasangan komparasi rerata

2. Merumuskan hipotesis yang bersesuaian dengan komparasi tersebut

3. Menentukan taraf signifikansi $(\alpha)=0,05$

4. Mencari harga statistik uji F dengan rumus sebagai berikut.

a) Komparasi rataan antar baris
Karena dalam penelitian ini hanya terdapat 2 kategori model pembelajaran maka jika $\mathrm{H}_{0 \mathrm{~A}}$ ditolak tidak perlu dilakukan komparasi pasca anava antar baris.

b) Uji Sceffe untuk komparasi rataan antar kolom adalah

$$
F_{. i-. j}=\frac{\left(\bar{X}_{. i}-\bar{X}_{. j}\right)^{2}}{R K G\left(\frac{1}{n_{. i}}+\frac{1}{n_{. j}}\right)}
$$

Daerah kritik untuk uji itu ialah DK = $\left\{\mathrm{F} \mid \mathrm{F}>(\mathrm{q}-1) \mathrm{F}_{\alpha ; \mathrm{q}-1, \mathrm{~N}-\mathrm{pq}}\right\}$

c) Komparasi rataan antar sel pada kolom yang sama 
Uji Sceffe untuk komparasi rataan sel pada kolom yang sama adalah sebagai berikut.

$$
F_{i j-k j}=\frac{\left(\bar{X}_{i j}-\bar{X}_{k j}\right)^{2}}{R K G\left(\frac{1}{n_{i j}}+\frac{1}{n_{k j}}\right)}
$$

Daerah kritik untuk uji itu ialah DK = $\left\{\mathrm{F} \mid \mathrm{F}>(\mathrm{pq}-1) \mathrm{F}_{\mathrm{\alpha} ; \mathrm{pq}-1, \mathrm{~N}-\mathrm{pq}}\right\}$

d) Komparasi rataan antar sel pada baris yang sama adalah sebagai berikut.

$$
F_{i j-i k}=\frac{\left(\bar{X}_{i j}-\bar{X}_{i k}\right)^{2}}{R K G\left(\frac{1}{n_{i j}}+\frac{1}{n_{i k}}\right)}
$$

Daerah kritik untuk uji itu ialah DK = $\left\{\mathrm{F} \mid \mathrm{F}>(\mathrm{pq}-1) \mathrm{F}_{\alpha ; \mathrm{pq}-1, \mathrm{~N}-\mathrm{pq}}\right\}$

e) Menentukan keputusan uji untuk masing-masing komparasi ganda

f) Menentukan kesimpulan dari keputusan uji yang sudah ada

(Rosa dkk, 2015: 375)

\section{Hasil}

Analisis deskriptif dimaksudkan untuk memberikan gambaran tentang kemampuan berpikir kritis dan potensi akademik peserta didik. Pendeskripsian karakteristik tersebut dapat dilihat melalui rata-rata hitung (mean), standar deviasi atau simpangan baku, varians, nilai maksimum, dan nilai minimum

Berdasarkan hasil analisis data variabel kemampuan berpikir kritis peserta didik, nilai minimum kemampuan berpikir kritis peserta didik kelompok model pembelajaran kooperatif tipe TAI adalah 54,44 sedangkan nilai maksimumnya adalah 83,33. Rata-rata nilai kemampuan berpikir kritis peserta didik adalah 70,40 , standar deviasi atau simpangan baku sebesar 6,39, modusnya adalah 70,00 dan Skewness sebesar 0,06.

Sedangkan untuk kelompok model pembelajaran Discovery Learning, nilai minimum adalah 53,33, nilai maksimum adalah 82,22 , modusnya adalah 72,22 , rerata hitungnya adalah 72,65, simpangan baku sebesar 6,34, dan skewness sebesar 0,07. Dari hal tersebut tampak bahwa rerata hasil kemampuan berpikir kritis peserta didik pada pembelajaran Discovery Learning lebih tinggi dari pada rerata hasil kemampuan berpikir kritis peserta didik kelas yang diajar menggunakan model pembelajaran kooperatif tipe TAI.

Jika dilihat dari simpangan baku, simpangan baku untuk kelas dengan pembelajaran kooperatif tipe TAI lebih tinggi daripada kelas dengan pembelajaran Discovery Learning. Untuk ukuran distribusinya, kedua kelas memilki koefisien kemiringan bernilai positif. Karena berharga positif, maka distribusi kedua kelas miring positif dengan kata lain, kecenderungan data mengumpul di bawah ratarata.

Berdasarkan hasil analisis variabel potensi akademik peserta didik diperoleh skor minimum pada kelompok model pembelajaran kooperatif tipe TAI adalah 400 sedangkan skor maksimumnya adalah 613. Rata-rata skor potensi akademik peserta didik adalah 512,56, simpangan baku adalah 57,24, modusnya adalah 560 dan Skewness sebesar $-0,83$.

Sedangkan untuk kelompok model pembelajaran Discovery Learning, diperoleh skor minimum adalah 387, skor maksimum adalah 613, modus sebesar 440, reratanya sebesar 510,33, simpangan baku sebesar 58,78, dan skewness sebesar 1,20. Dari hal tersebut tampak bahwa rata-rata hasil potensi akademik peserta didik pada kelas dengan pembelajaran kooperatif tipe TAI lebih tinggi dari pada rerata hasil potensi akademik kelas dengan pembelajaran Discovery Learning. Jika dilihat dari simpangan baku, simpangan baku untuk kelas dengan pembelajaran kooperatif tipe TAI lebih rendah daripada kelas dengan pembelajaran Discovery Learning.

Jika dilihat dari ukuran distribusinya, kelas dengan pembelajaran TAI mempunyai koefisien kemiringan bernilai negatif. Karena berharga negatif, maka distribusinya miring negatif dengan kata lain, kecenderungan data mengumpul di atas rata-rata. Sedangkan untuk kelas dengan pembelajaran Discovery Learning, koefisien kemiringannya bernilai positif dengan kata lain, kecenderungan data mengumpul di bawah rata-rata.

Tingkat potensi akademik peserta didik dalam penelitian ini dikategorikan dalam tiga tingkat berdasarkan hasil skor dari tes potensi akademik yang diberikan yaitu tingkat potensi 
akademik tinggi, tingkat potensi akademik sedang, dan tingkat potensi akademik rendah. Adapun batas kelompok potensi akademik peserta didik ialah dikategorikan dengan kriteria berikut.

1) Potensi akademik tinggi $=X_{i}>540,25$
2) Potensi akademik sedang $=482,64 \leq$ $X_{i} \leq 540,25$

3) Potensi akademik rendah $=X_{i}<482,64$

Deskripsi kemampuan berpikir kritis berdasarkan tingkat potensi akademik peserta didik disajikan pada tabel 3 berikut.

\section{Tabel 3}

Deskripsi Kemampuan Berpikir Kritis Peserta Didik Berdasarkan

Tingkat Potensi Akademik

\begin{tabular}{|c|c|c|c|c|c|c|}
\hline \multirow{2}{*}{$\begin{array}{c}\text { Model } \\
\text { Pembelajaran }\end{array}$} & \multirow{2}{*}{ Statistik } & \multicolumn{3}{|c|}{ Potensi Akademik } & \multirow[t]{2}{*}{$\mathbf{N}$} & \multirow{2}{*}{$\begin{array}{l}\text { Rata-rata } \\
\text { Marginal }\end{array}$} \\
\hline & & Tinggi & Sedang & Rendah & & \\
\hline \multirow{4}{*}{$\begin{array}{c}\text { Kooperatif tipe } \\
\text { Team Assisted } \\
\text { Individualization }\end{array}$} & $\mathrm{N}$ & 15 & 9 & 12 & \multirow{4}{*}{36} & \multirow{4}{*}{70,40} \\
\hline & Rata-rata $(\bar{X})$ & 75,11 & 69,76 & 65,00 & & \\
\hline & Simpangan Baku (s) & 3,70 & 5,98 & 4,91 & & \\
\hline & Skewness (Sk) & $-0,12$ & $-0,04$ & $-1,02$ & & \\
\hline \multirow{4}{*}{$\begin{array}{c}\text { Pembelajaran } \\
\text { Discovery Learning }\end{array}$} & $\mathrm{N}$ & 13 & 12 & 11 & \multirow{4}{*}{36} & \multirow{4}{*}{72,65} \\
\hline & Rata-rata $(\bar{X})$ & 77,18 & 74,35 & 65,46 & & \\
\hline & Simpangan Baku (s) & 3,26 & 2,25 & 5,95 & & \\
\hline & Skewness (Sk) & $-0,53$ & $\begin{array}{l}-0,04 \\
\end{array}$ & $-0,20$ & & \\
\hline \multicolumn{2}{|c|}{$\frac{1}{N}$} & 28 & 21 & 23 & \multirow{2}{*}{\multicolumn{2}{|c|}{ - }} \\
\hline \multicolumn{2}{|c|}{ Rata-rata Marginal } & 76,07 & 72,38 & 65,22 & & \\
\hline
\end{tabular}

Berdasarkan hasil analisis kemampuan berpikir kritis peserta didik berdasarkan tingkat potensi akademik pada masing-masing kelompok pembelajaran diperoleh hasil yakni rerata kemampuan berpikir kritis tertinggi untuk model pembelajaran kooperatif tipe TAI dengan potensi akademik tinggi adalah 75,11, untuk potensi akademik sedang adalah 69,76 dan rerata untuk potensi akademik rendah adalah 65,00. Sedangkan untuk model Discovery Learning, rerata kemampuan berpikir kritis peserta didik dengan potensi akademik tinggi adalah 77,18 , untuk potensi akademik sedang adalah 74,35 , dan rerata untuk potensi akademik rendah adalah 65,46.

Ukuran distribusi untuk semua kelompok memilki koefisien kemiringan bernilai negatif. Hal ini tampak dari besaran skewness yang bernilai negatif untuk semua kelompok. Karena berharga negatif, maka distribusi untuk setiap kelompok miring negatif, dengan kata lain, kecenderungan data mengumpul di atas rata-rata. Dari tabel 5 dapat dilihat bahwa nilai rata-rata tertinggi terdapat pada peserta didik yang diajar dengan model pembelajaran Discovery Learning dengan potensi akademik tinggi. Sedangkan rerata terendah terdapat pada peserta didik yang diajar dengan model kooperatif tipe TAI dengan potensi akademik rendah.

Tahap selanjutnya dalam analisis data adalah analisis inferensial. Melalui analisis inferensial kita dapat mengetahui apakah hipotesis dalam penelitian ini diterima atau ditolak. Dalam analisis inferensial, terdapat beberapa tahap analisis yang menjadi prasyarat untuk melakukan analisis uji hipotesis yaitu analisis uji normalitas data dan analisis homogenitas data. Uji normalitas dilakukan lima kali yaitu uji normalitas kemampuan berpikir kritis untuk populasi model pembelajaran (kooperatif tipe TAI dan Discovery Learning) dan populasi tingkat potensi akademik peserta didik (tinggi, sedang, dan rendah. Pengujian dilakukan dengan uji Kolmogrov-Smirnov dengan bantuan SPSS. Hasil perhitungannya disajikan dalam tabel 4. 
Tabel 4

Hasil Analisis Statistik Uji Normalitas Data Kemampuan Berpikir Kritis

\begin{tabular}{|l|r|r|r|r|r|}
\hline \multicolumn{7}{|c|}{ One-Sample Kolmogorov-Smirnov Test } \\
\hline & $\begin{array}{c}\text { Koop. Tipe } \\
\text { TAI }\end{array}$ & Model DL & $\begin{array}{c}\text { Potensi } \\
\text { Tinggi }\end{array}$ & $\begin{array}{c}\text { Potensi } \\
\text { Sedang }\end{array}$ & $\begin{array}{c}\text { Potensi } \\
\text { Rendah }\end{array}$ \\
\hline $\mathrm{N}$ & 36 & 36 & 28 & 21 & 23 \\
\hline Kolmogorov-Smirnov Z & 0,849 & 0,923 & 0,645 & 0,920 & 1,076 \\
\hline Asymp. Sig. (2-tailed) & 0,466 & 0,362 & 0,799 & 0,366 & 0,197 \\
\hline
\end{tabular}

Hasil uji normalitas menunjukkan data seluruh kelompok berdistribusi normal. Hal ini ditunjukkan dari $p$-value kemampuan berpikir kritis untuk kelompok model TAI adalah 0,466 $>$ dari 0,05. p-value kemampuan berpikir kritis untuk kelompok model Discovery Learning adalah $0,362>0,05$. p-value kemampuan berpikir kritis untuk kelompok tingkat potensi akademik tinggi adalah 0,799>0,05. p-value kemampuan berpikir kritis untuk kelompok tingkat potensi akademik sedang adalah 0,366 >
0,05. Dan $p$-value kemampuan berpikir kritis untuk kelompok tingkat potensi akademik rendah adalah 0,197 > 0,05. Karena seluruh kelompok mempunyai probabiliti lebih besar dari 0,05 maka seluruh kelompok berasal dari populasi yang berdistribusi normal.

Uji homogenitas variansi populasi yang digunakan dalam penelitian ini adalah uji Levene. Rangkuman hasil uji homogenitas dapat di lihat pada Tabel 5 dan Tabel 6

\section{Tabel 5}

Uji Homogenitas Kemampuan Berpikir Kritis Ditinjau Dari Model Pembelajaran

\begin{tabular}{|c|c|c|c|}
\hline & & Value Label & $\mathbf{N}$ \\
\hline \multirow{2}{*}{ Kelompok } & 1,00 & $\begin{array}{l}\text { Model Kooperatif tipe Team } \\
\text { Assisted Individualization }\end{array}$ & 36 \\
\hline & 2,00 & $\begin{array}{l}\text { Model Pembelajaran Discovery } \\
\text { Learning }\end{array}$ & 36 \\
\hline \multicolumn{4}{|c|}{ Levene's Test of Equality of Error Variances ${ }^{\mathrm{a}}$} \\
\hline \multicolumn{4}{|c|}{ Dependent Variable: Kemampuan Berpikir Kritis } \\
\hline $\mathrm{F}$ & $\mathrm{df} 1$ & df2 & Sig. \\
\hline 0,099 & 1 & 70 & 0,754 \\
\hline
\end{tabular}

Hasil uji homogenitas menggunakan uji Levene. Pada Tabel 5. tampak bahwa kemampuan berpikir kritis ditinjau dari model pembelajaran adalah homogen. Hal ini ditunjukkan dari $p$-value yang diperoleh adalah $0,754>0,05$.

Tabel 6

Uji Homogenitas Kemampuan Berpikir Kritis

Peserta didik Ditinjau Dari Potensi Akademik

\begin{tabular}{|l|l|l|r|}
\hline \multicolumn{2}{|l|}{} & \multicolumn{1}{|c|}{ Value Label } & N \\
\hline \multirow{3}{*}{ Kelompok } & 1,00 & Potensi Akademik Tinggi & 28 \\
\cline { 2 - 5 } & 2,00 & Potensi Akademik Sedang & 21 \\
\cline { 2 - 5 } & 3,00 & Potensi Akademik Rendah & \\
\hline \multicolumn{5}{|c|}{ Levene's Test of Equality of Error Variances ${ }^{\mathrm{a}}$} \\
\hline Dependent Variable: Kemampuan Berpikir Kritis & \multicolumn{1}{c|}{ Sig. } \\
\hline F & df1 & \multicolumn{1}{|c|}{ df } & 0,450 \\
\hline
\end{tabular}




\section{Jurnal Penelitian Pendididikan Matematika Volume 7 No.2 Mei 2019}

Tabel 6. menunjukkan bahwa kemampuan berpikir kritis peserta didik ditinjau dari tingkat potensi akademik adalah homogen. Hal ini dilihat dari nilai probabiliti yang diperoleh yakni $0,450>0,05$.

Setelah dilakukan uji prasyarat selanjutnya dilakukan uji hipotesis yakni analisis variansi dua jalan. Tujuan dari analisis variansi dual jalan adalah untuk menguji signifikansi efek dua variabel yaitu model pembelajaran dan level potensi akademik peserta didik terhadap satu variabel terikat yaitu kemampuan berpikir kritis matematis. Hal lainnya adalah untuk menguji signifikansi interaksi kedua variabel bebas tersebut terhadap variabel terikat. Pengujian dalam penelitian ini menggunakan analisis variansi dua jalan dengan ukuran sel tak sama dan hasilnya disajikan pada Tabel 7 berikut.

\section{Tabel 7}

Rangkuman Analisis Variansi Dua Jalan

\begin{tabular}{|c|c|c|c|c|c|c|}
\hline $\begin{array}{c}\text { Sumber } \\
\text { Varians }\end{array}$ & JK & $\mathbf{d b}$ & $\mathbf{R J K}$ & $\mathbf{F}_{\mathbf{~}}$ & $\mathbf{F}_{\text {tabel }}$ & $\begin{array}{c}\text { Keputusan } \\
\text { Uji }\end{array}$ \\
\hline Antar (A) & 91,28 & 1 & 91,28 & 4,70 & 3,99 & $\mathrm{H}_{0}$ ditolak \\
\hline Antar (B) & 1509,28 & 2 & 754,64 & 38,88 & 3,14 & $\mathrm{H}_{0}$ ditolak \\
\hline Int. AB & 48,25 & 2 & 24,13 & 1,24 & 3,14 & $\mathrm{H}_{0}$ diterima \\
\hline $\begin{array}{c}\text { Dalam } \\
\text { (Error) }\end{array}$ & 1280,80 & 66 & 19,41 & - & - & - \\
\hline Total & 2929,61 & 71 & - & - & - & - \\
\hline
\end{tabular}

Dari tabel di atas tampak bahwa $\mathrm{F}_{\mathrm{oA}}>\mathrm{F}_{\text {tabel }}$, $\mathrm{F}_{\mathrm{oB}}>\mathrm{F}_{\text {tabel }}, \quad \mathrm{F}_{\mathrm{OAB}}<\mathrm{F}_{\text {tabel }}$, sehingga diperoleh keputusan uji $\mathrm{H}_{0 \mathrm{~A}}$ ditolak, $\mathrm{H}_{0 \mathrm{~B}}$ ditolak dan $\mathrm{H}_{0 \mathrm{AB}}$ diterima. Demikian dapat disimpulkan sebagai berikut

a) Berdasarkan hasil perhitungan pada analisis variansi dua jalan dengan ukuran sel tak sama, untuk sumber variansi model pembelajaran diperoleh nilai $\mathrm{F}_{\mathrm{oA}}=4,70>$ $3,99=\mathrm{F}_{0,05 ; 1,66}$, sehingga $\mathrm{H}_{0 \mathrm{~A}}$ ditolak. Dengan ditolaknya $\mathrm{H}_{0 \mathrm{~A}}$ berarti peserta didik yang diberi pembelajaran dengan model pembelajaran kooperatif tipe Team Assisted Individualization dan peserta didik yang diberi pembelajaran Discovery Learning mempunyai kemampuan berpikir kritis yang berbeda

b) Berdasarkan hasil perhitungan pada analisis variansi dua jalan dengan ukuran sel tak sama untuk kategori potensi akademik diperoleh nilai $\mathrm{F}_{\mathrm{oB}}=38,88>3,14=\mathrm{F}_{0,05 ; 2,66}$ sehingga $\mathrm{H}_{0 \mathrm{~B}}$ ditolak. Dengan ditolaknya $\mathrm{H}_{0 \mathrm{~B}}$ berarti terdapat perbedaan kemampuan berpikir kritis antara peserta didik yang mempunyai potensi akademik tinggi, sedang, dan rendah

c) Berdasarkan hasil perhitungan pada analisis variansi dua jalan dengan ukuran sel tak sama untuk sumber variansi interaksi antara model pembelajaran dengan skor potensi akademik peserta didik diperoleh nilai $\mathrm{F}_{\mathrm{OAB}}$ $=1,24<3,14=\mathrm{F}_{0,05 ; 2,66}$ sehingga $\mathrm{H}_{0 \mathrm{AB}}$ diterima. Dengan diterimanya $\mathrm{H}_{0 \mathrm{AB}}$ berarti tidak terdapat pengaruh interaksi antara model pembelajaran dan potensi akademik peserta didik terhadap kemampuan berpikir kritis peserta didik

Setelah dilakukan analisis varians dua jalan dengan sel tak sama selanjutnya dilakukan uji rataan dengan uji komparasi ganda atau uji lanjut pasca anava. Teknik yang digunakan dalam uji komparasi ganda adalah dengan metode Scheffe'. Untuk melakukan komparasi ganda, dicari terlebih dahulu rataan masingmasing sel dan rataan marginal, yang hasilnya tampak pada Tabel 8. berikut. 


\section{Tabel 8}

Rataan Masing-masing Sel dan Rataan Marginal

\begin{tabular}{|c|c|c|c|c|}
\hline \multirow{2}{*}{ Model Pembelajaran } & \multicolumn{2}{|l|}{ Skor Potensi Akademik Peserta didik } & \multirow{2}{*}{$\begin{array}{c}\text { Rataan } \\
\text { Marginal }\end{array}$} \\
\cline { 2 - 4 } & Tinggi & Sedang & Rendah & \\
\hline Kooperatif Tipe TAI & 75,11 & 69,76 & 65,00 & 70,40 \\
\hline Discovery Learning & 77,18 & 74,35 & 65,46 & 72,65 \\
\hline Rataan Marginal & 76,07 & 72,38 & 65,22 & - \\
\hline
\end{tabular}

Dari hasil uji anava $\mathrm{H}_{0 \mathrm{~A}}$ ditolak, ini berarti peserta didik yang diberi pembelajaran dengan model kooperatif tipe TAI dan peserta didik yang diberi pembelajaran dengan model Discovery Learning mempunyai kemampuan berpikir kritis yang berbeda. Dalam penelitian ini, karena variabel model pembelajaran hanya mempunyai dua nilai (yaitu model pembelajaran kooperatif tipe TAI dan model Discovery Learning), maka tidak perlu dilakukan komparasi rataan antar baris pasca anava. Untuk mengetahui model pembelajaran mana yang dapat memberikan kemampuan berpikir kritis lebih baik, cukup melihat rataan marginalnya.

Dari rataan marginal pada Tabel 8 tampak bahwa rerata kemampuan berpikir kritis peserta didik yang diberi pembelajaran dengan model pembelajaran kooperatif tipe TAI sebesar 70,40 Sedangkan rerata kemampuan berpikir kritis untuk peserta didik yang diajar dengan model Discovery Learning sebesar 72,65. Ini menunjukkan bahwa rataan marginal yang diperoleh peserta didik dengan model pembelajaran Discovery Learning lebih tinggi daripada rataan peserta didik yang diberi pembelajaran kooperatif tipe TAI, sehingga dapat disimpulkan bahwa peserta didik yang diberi pembelajaran dengan model kooperatif tipe TAI tidak lebih baik kemampuan berpikir kritisnya dibandingkan dengan peserta didik yang diberi pembelajaran dengan moel Discovery Learning.

Selanjunya, dari hasil uji anava $\mathrm{H}_{0 \mathrm{~B}}$ ditolak, ini berarti terdapat perbedaan kemampuan berpikir kritis antara peserta didik yang mempunyai potensi akademik tinggi, sedang, dan rendah. Dalam penelitian, karena variabel potensi akademik peserta didik mempunyai tiga nilai (potensi akademik rendah, potensi akademik sedang, dan potensi akademik rendah), maka dilakukan uji lanjut untuk melakukan pelacakan terhadap perbedaan rerata setiap pasangan kolom (potensi akademik tinggi, potensi akademik sedang, potensi akademik rendah). Rangkuman komparasi rataan antar kolom disajikan pada Tabel 9. berikut.

\section{Tabel 9}

Rangkuman Komparasi Rataan Antar Kolom

\begin{tabular}{|c|c|c|c|}
\hline $\mathbf{H}_{\mathbf{0}}$ & $\mathbf{F}_{\mathbf{0}}$ & $\mathbf{2 F}_{\mathbf{0 , 0 5} ; \mathbf{2}, \mathbf{6 6}}$ & Keputusan \\
\hline$\mu_{B 1}=\mu_{B 2}$ & 8,42 & 6,28 & $\mathrm{H}_{0}$ ditolak \\
\hline$\mu_{B 1}=\mu_{B 3}$ & 76,59 & 6,28 & $\mathrm{H}_{0}$ ditolak \\
\hline$\mu_{B 2}=\mu_{B 3}$ & 28,99 & 6,28 & $\mathrm{H}_{0}$ ditolak \\
\hline
\end{tabular}

Berdasarkan tabel di atas dapat disimpulkan bahwa

i) Komparasi antara kemampuan berpikir kritis peserta didik dengan potensi akademik tinggi dan sedang diperoleh nilai $F_{B 1-B 2}=8,42>2 \mathrm{~F}_{0,05 ; 2,66}=6,28$ maka $\mathrm{H}_{0}$ ditolak. Dengan ditolaknya $\mathrm{H}_{0}$ berarti kemampuan berpikir kritis peserta didik yang mempunyai potensi akademik tinggi tidak sama dengan peserta didik yang mempunyai potensi akademik sedang

ii) Komparasi antara kemampuan berpikir kritis peserta didik dengan potensi akademik tinggi dan rendah diperoleh nilai $F_{B 1-B 3}=76,59>2 \mathrm{~F}_{0,05 ; 2,66}=6,28$ maka $\mathrm{H}_{0}$ ditolak. Dengan ditolaknya $\mathrm{H}_{0}$ berarti kemampuan berpikir kritis peserta didik yang mempunyai potensi akademik tinggi tidak sama dengan peserta didik yang mempunyai potensi akademik rendah 


\section{Jurnal Penelitian Pendididikan Matematika Volume 7 No.2 Mei 2019}

iii) Komparasi antara kemampuan berpikir kritis peserta didik dengan potensi akademik sedang dan rendah diperoleh nilai $F_{B 2-B 3}=28,99>2 \mathrm{~F}_{0,05 ; 2,66}=6,28$ maka $\mathrm{H}_{0}$ ditolak. Dengan ditolaknya $\mathrm{H}_{0}$ berarti kemampuan berpikir kritis peserta didik yang mempunyai potensi akademik sedang tidak sama dengan peserta didik yang mempunyai potensi akademik rendah.

Pada efek interaksi $\mathrm{AB}$ dari hasil uji anava diketahui $\mathrm{H}_{0 \mathrm{AB}}$ diterima, ini berarti tidak terdapat pengaruh interaksi antara model pembelajaran dan potensi akademik terhadap kemampuan berpikir kritis peserta didik. Dapat disimpulkan bahwa karakteristik perbedaan antara model pembelajaran kooperatif tipe TAI dan model pembelajaran Discovery Learning untuk setiap kategori potensi akademik adalah sama. Untuk melihat manakah yang memberikan kemampuan berpikir kritis lebih baik, tidak perlu dilakukan komparasi rataan antar sel pada baris atau kolom yang sama, kesimpulan perbandingan antar sel mengacu pada kesimpulan perbandingan rataan marginalnya.

\section{Pembahasan}

Gambaran kemampuan berpikir kritis setelah diberi perlakuan model pembelajaran (kooperatif tipe TAI dan Discovery Learning) dengan potensi akademik (tinggi, sedang, rendah) memiliki rerata, simpangan baku, dan koefisien kemiringan atau skewness. Nilai rerata tertinggi terdapat pada peserta didik yang diajar dengan model pembelajaran Discovery Learning dengan potensi akademik tinggi. Nilai rerata kemampuan berpikir kritis terendah terdapat pada peserta didik yang diajar dengan model pembelajaran kooperatif tipe TAI dengan potensi akademik rendah. Hal ini menunjukkan bahwa secara umum model pembelajaran memberikan pengaruh terhadap kemampuan berpikir kritis. Peserta didik yang diajar dengan model pembelajaran kooperatif tipe TAI mempunyai kemampuan berpikir kritis yang berbeda dengan peserta didik yang diajar dengan model pembelajaran Discovery Learning.

Rataan marginal yang diperoleh peserta didik yang diberi pembelajaran dengan model pembelajaran Discovery Learning lebih tinggi dibandingkan dengan rataan marginal yang diperoleh peserta didik yang diberi pembelajaran dengan model kooperatif tipe TAI, hal ini menunjukkan bahwa peserta didik yang diberi pembelajaran dengan model kooperatif tipe TAI tidak lebih baik kemampuan berpikir kritisnya dibandingkan dengan peserta didik yang diberi pembelajaran dengan model pembelajaran Discovery Learning.

Keunggulan model pembelajaran Discovery Learning yakni peserta didik sudah terbiasa menggunakannya, sehingga peserta didik tidak mengalami kesulitan dalam prosesnya. Sedangkan TAI merupakan hal yang baru bagi peserta didik, sehingga mereka agak bingung ketika belajar menggunakan model ini. Pada model TAI, di awal pertemuan, ketika selesai mengerjakan lembar kerja secara individual dan kemudian menuju ke kelompok masing-masing membutuhkan waktu yang cukup lama, sehingga terkadang kelas mulai gaduh, dan beberapa peserta didik mulai mengganggu peserta didik lainnya.

Hal lainnya adalah kelas dengan model TAI ada jadwal pembelajaran matematika diberikan setelah jam olahraga sehingga mengakibatkan diskusi tidak berjalan maksimum. Hal lain disebabkan pada kelas TAI pembentukan kelompok diskusi dengan mempertimbangkan kemampuan yang berbeda kurang berkenan pada peserta didik dikarenakan mereka enggan berpisah dengan kelompok sehari-harinya. Padahal salah satu unsur pembelajaran kooperatif adalah adanya saling ketergantungan yang positif, peserta didik merasa bahwa keberhasilan atau kegagalan terletak dalam kerja mereka bersama-sama. Agar peserta didik dapat bekerja sama dengan baik di dalam kelompoknya mereka perlu ketrampilan-ketrampilan kooperatif.

Selain model pembelajaran, tingkat potensi akademik peserta didik juga memberikan pengaruh terhadap kemampuan berpikir kritis. Kemampuan berpikir kritis peserta didik dengan potensi akademik tinggi berbeda dengan peserta didik dengan potensi akademik sedang dan rendah. Secara teoritis, potensi akademik menunjukkan profil kemampuan berpikir sesorang. Sehingga peserta didik dengan potensi akademik tinggi memiliki kemampuan berpikir yang tinggi pula.

Pengkategorian potensi akademik diperoleh dari hasil tes potensi akademik. Tes potensi akademik merupakan tes yang berkaitan 
dengan kemampuan akademis. Tes ini memiliki substansi terkait kemampuan berpikir seseorang. Sehingga jika seorang peserta didik memilki skor tes yang tinggi berarti peserta didik tersebut memiliki profil kemampuan berpikir yang tinggi juga. Sehingga, peserta didik dengan tingkat potensi akademik tinggi memilki kemampuan berpikir kritis lebih baik daripada peserta didik dengan tingkatan sedang dan rendah dan peserta didik dengan tingkat potensi akademik sedang memilki kemampuan berpikir kritis yang lebih baik daripada peserta didik dengan tingkatan rendah.

Skor potensi akademik tertinggi yang diperoleh peserta didik adalah 613 dengan hasil kemampuan berpikir kritis pada transformasi sebesar 73,33. Berdasarkan teori, skor TPA 613 adalah skor TPA untuk lolos seleksi S3, dengan demikian secara teori peserta didik dengan skor ini dapat menempuh pendidikan hingga jenjang S3. Sedangkan skor potensi akademik terendah adalah 387 dengan hasil kemampuan berpikir kritis pada materi transformasi sebesar 65,56. Berdasarkan teori, skor ini berada di rentang nilai minimum untuk lolos seleksi S1. Dengan demikian peserta didik dengan skor ini, secara teori dapat menempuh pendidikan hingga jenjang S1.

Skor hasil tes potensi akademik ditujukan untuk mengukur kemampuan berpikir yang dimilki peserta didik saat ini, bukan untuk mengukur tingkat prestasi belajar peserta didik pada materi yang diajarkan di sekolah. Tingkat prestasi belajar ditentukan oleh sejauh mana penguasaan materi pelajaran oleh peserta didik. Sehingga walaupun secara teori hasil tes potensi akademik peserta didik dapat memberikan gambaran jenjang pendidikan yang dapat ditempuh, tetapi hasil tes ini masih belum menggambarkan jurusan atau bidang pendidikan yang nantinya dapat dipilih oleh peserta didik. Untuk memilih jurusan yang diinginkan maka peserta didik harus memilki tingkat penguasaan materi pelajaran yang dibutuhkan dalam jurusan yang diinginkannya.

Dari segi kemampuan berpikir kritis peserta didik pada materi transformasi, potensi akademik menghasilkan kemampuan yang berbeda dari setiap tingkatannya. Dengan melihat rataan marginal kelompok potensi akademik, rataan marginal yang diperoleh peserta didik yang mempunyai potensi akademik tinggi lebih tinggi dibandingkan dengan peserta didik yang mempunyai potensi akademik sedang. Dengan demikian peserta didik yang mempunyai potensi akademik tinggi lebih baik kemampuan berpikir kritisnya dibandingkan dengan peserta didik yang mempunyai potensi akademik sedang.

Rataan marginal yang diperoleh peserta didik yang mempunyai potensi akademik tinggi lebih tinggi dibandingkan dengan peserta didik yang mempunyai potensi akademik rendah. Dengan demikian peserta didik yang mempunyai potensi akademik tinggi lebih baik kemampuan berpikir kritisnya dibandingkan dengan peserta didik yang mempunyai potensi akademik rendah.

\section{Simpulan dan Saran}

\section{Simpulan}

Berdasarkan hasil penelitian dan pembahasan, maka dapat disimpulkan.

1. Gambaran kemampuan berpikir kritis peserta didik setelah diberi perlakuan model pembelajaran dengan potensi akademik memiliki rerata, simpangan baku, dan koefisien kemiringan atau skewness yang berbeda antar tiap kelompok. Hal ini menunjukkan bahwa secara umum model pembelajaran dan potensi akademik memberikan pengaruh terhadap kemampuan berpikir kritis peserta didik

2. Terdapat perbedaan kemampuan berpikir kritis antara peserta didik yang diberi perlakuan model pembelajaran kooperatif tipe TAI dan Discovery Learning pada materi transformasi. Peserta didik yang diberi pembelajaran dengan model pembelajaran kooperatif tipe TAI tidak lebih baik kemampuan berpikir kritisnya dibandingkan dengan peserta didik yang diberi pembelajaran dengan model Discovery Learning.

3. Terdapat pengaruh potensi akademik peserta didik terhadap kemampuan berpikir kritis pada materi transformasi. Peserta didik yang mempunyai potensi akademik tinggi lebih baik kemampuan berpikir kritisnya dibandingkan dengan peserta didik dengan potensi akademik sedang maupun yang rendah dan peserta didik yang mempunyai potensi akademik sedang lebih baik 
kemampuan berpikir kritisnya dibandingkan dengan peserta didik dengan potensi akademik rendah

4. Tidak terdapat interaksi antara model pembelajaran dengan potensi akademik terhadap kemampuan berpikir kritis peserta didik pada mater transformasi. Sehingga baik pada model pembelajaran kooperatif tipe TAI maupun model pembelajaran Discovery Learning, peserta didik yang mempunyai potensi akademik tinggi lebih baik kemampuan berpikir kritisnya dibandingkan dengan peserta didik dengan potensi akademik sedang. Peserta didik yang mempunyai potensi akademik sedang lebih baik kemampuan berpikir kritisnya dibandingkan dengan peserta didik yang mempunyai potensi akademik rendah. Peserta didik yang mempunyai potensi akademik tinggi, mereka yang diberi pembelajaran dengan model pembelajaran kooperatif tipe TAI tidak lebih baik kemampuan berpikir kritisnya dibandingkan dengan peserta didik yang diberi pembelajaran dengan model Discovery Learning. Hal yang sama juga berlaku untuk peserta didik yang memiliki potensi akademik sedang dan rendah

\section{Saran}

Berdasarkan temuan yang penulis temukan dalam penelitian ini, ada beberapa saran penulis terkait penelitian ini, diantaranya

1. Kemampuan berpikir kritis matematis peserta didik dengan menggunakan pembelajaran kooperatif tipe TAI tidak lebih baik dari pada peserta didik yang diberikan pembelajaran Discovery Learning sehigga untuk guru, jika untuk meningkatkan kemampuan berpikir kritis peserta didik maka tetap menggunakan pembelajaran Discovery Learning

2. Model pembelajaran kooperatif tipe TAI membutuhkan waktu yang cukup lama. Untuk itu, bagi guru yang hendak menggunakan model pembelajaran kooperatif tipe TAI dalam pembelajaran matematika di kelas diharapkan dapat mempersiapkan dan melaksanakan pembelajaran dengan seefektif mungkin agar pembelajaran dapat diselesaikan dengan baik

\section{Daftar Pustaka}

Afiah, I. (2012). Korelasi antara Potensi Akademik, Motivasi Belajar, dengan Prestasi Akademik pada Siswa Kelas X Program Unggulan MAN Tambakberas Jombang, Skripsi. UIN Maulana Malik Ibrahim Malang: Malang.

Arikunto, Suharsimi. (2017). Dasar-dasar Evaluasi Pendidikan. Jakarta: Bumi Aksara.

Azwar, S. (2008). Kualitas Tes Potensi Akademik Versi 07A. Jurnal Penelitian dan Evaluasi Pendidikan Nomor 2 Tahun XII 2008.

Hendriana, H dan Soemarmo, U. (2014). Penilaian Pembelajaran Matematika. Bandung: Refika Aditama.

Jihad, A. dan Haris, A. (2012). Evaluasi Pembelajaran. Yogyakarta: Multi Presindo.

Johnson, E.B. (2012). CTL (Contextual Teaching \& Learning). Menjadikan KegiatanBelajar-Mengajar Mengasyikkan dan Bermakna. Bandung: Kaifa.

Kadir. (2018). STTATISTIKA TERAPAN. Konsep Contoh dan Analisis Data dengan Program SPSS/Lisrel dalam Penelitian. Depok: Rajawali Pers.

Nugroho, A. (2018). HOTS: Higher Order Thinking Skills. Jakarta: Grasindo.

Poerwanti, E. (2008). Assesmen Pembelajaran. Departemen Pendidikan Nasional : Jakarta.

Rosa, Yuvita Erpina, dkk. (2015). Metode Scheffe Dalam Uji Komparasi Ganda Analisis Dua Faktor Dengan Interaksi. Buletin Ilmiah Matf. Stat. Dan Terapannya (Bimaster).. Vol 04, No.3, 2015, hal: 375

Sarwadi. (2015). Big Drilling Soal + Pembahasan Tes Potensi Akademi (TPA). Yogyakarta: Pustaka Baru Press. 